Martin Hapla

\title{
Is the Separation of Powers a Useless Concept? The Components and Purpose of the Separation of Powers ${ }^{1}$
}

\section{Introduction}

The separation of powers is a significant topic. It is an important part of discussions among not only lawyers but also politicians and journalists. Something like this would not be possible if the issue were resolved. The separation of powers keeps raising new questions. But what is the nature of these questions? When Eoin Carolan considered the same in the context of Great Britain, he concluded that there is no political or judicial debate over the important normative assumptions of the separation of powers. This issue rather remains hidden in the background, and only some partial problems of the institutional arrangement are discussed, such as the position of the Lord Chancellor or the House of Lords. ${ }^{2}$ We can put this criticism on an even more general plane and say that the theoretical and philosophical contexts of the whole issue remain neglected. In fact, many of the difficult-to-solve disputes over the status of various state bodies might be, in my opinion, rooted in some of the non-articulated general problems. It is, therefore, one of the objectives of this paper to bring these problems to the fore and examine the separation of powers from the point of view of legal theory and philosophy. Nowadays, the importance of general institutional issues is quite extraordinary. ${ }^{3}$ We live in a time when we hardly agree on any ethical or political principles. This raises the need for fairly set up institutions that would enable us to resolve the disputes that arise from such disagreements. ${ }^{4}$

1 The paper is a result of the project Axiologické základy právního myšlení Code: MUNI/A/0828/2016.

2 E. Carolan, The New Separation of Powers: A Theory for the Modern State, New York 2009, pp. 33-34.

3 To this, cf.J. Waldron, Political Political Theory. Essays on Institutions, Cambridge, London 2016, p. 5. The author also reminds us that this is a traditional issue. Examination of political institutions has been a topic of theory since Aristotle. Vid. ibid, p. 20.

4 Cf. ibid. Our disagreement on ethical, religious, and political values has already been addressed by John Rawls, who constructed his concept of overlapping consensus as a reaction. To this, vid. 
What if exploring this issue opens Pandora's box? Could it be eventually shown that the separation of powers is such a difficult-to-understand principle that we cannot actually draw any concrete institutional applications from it? We should not close our eyes to such fears but rather the opposite. If they prove justified, the question remains how we should treat the separation of powers. Should we try to innovate it in some way, to formulate its new, more appropriate concept? Or should we rather dismiss it completely and replace it with something else? Is the separation of powers a useless concept? I will try to answer these questions in two articles. In the first one I deal with the issue of components of the separation of powers, their mutual relationships and their purposes.

\section{The Components of Separation of Powers}

What exactly do we mean by the separation of powers? At first glance it seems to be a rather confusing concept ${ }^{5}$ because it combines several and very different components. For example, Jeremy Waldron differentiates five separate principles within its framework: the principle of the separation of power; the principle of the dispersal of power; the principle of checks and balances; the principle of bicameralism; and the principle of federalism consisting in the division of power between the federal government and the components that represent its individual states. ${ }^{6}$ In contrast, M. J. Vile distinguishes the separation of agencies, the separation of functions, the separation of persons, and also the system of checks and balances. ${ }^{7}$ We see that both divisions differ in certain ways, but they also have a lot in common. I am of the opinion that there are two fundamental questions standing in the background of the ideas on the separation of powers: The first one is who should perform what state function, and second, what should the mutual relations between individual state bodies be? Within both, we can think of different models. If, in the context of the first, we advocate the requirement that each function be exercised by a different state body, we can speak of the separation of functions. The opposite of this principle is the situation where one function is exercised by several state bodies, or where one state body exercises multiple functions. A different question is whether individual state bodies should be (as much as possible) independent or mutually interconnected by different (control or other) mechanisms. In such a framework, we consider whether we should apply the require-

e.g., J. Rawls, The Idea of an Overlapping Consensus, in: “Oxford Journal of Legal Studies”, 1987, no. 1 , pp. 1-25.

5 Cf. M. J. C. Vile, Constitutionalism and the Separation of Powers, Indianopolis 1998, p. 2.

6 J. Waldron, op. cit., p. 49.

7 M. J. C. Vile, op. cit., p. 17 et seq. 
ments of institutional independence or the system of checks and balances. ${ }^{8}$ In practice, we can combine a variety of these components - for example, we may require that individual state functions are exercised by different systems of state bodies that would be institutionally independent, etc. Or we can also reflect some of these principles onto different levels of the state organization and deal with the question, for instance, of what the interrelations between the state government and local self-governments should be, and of whether they should exercise different functions.

\section{The Separation of Functions}

The separation of functions and the independence of individual state bodies has not been sufficiently distinguished in the scholarly iterature, not even by critics of the separation of powers. In order to make their views easier to understand, we will combine both into the term "the strict separation of powers" in the first paragraphs of this chapter. Later in the text, we will attempt to distinguish between the two concepts again.

Although Montesquieu is sometimes considered to be the founder of the idea of the strict separation of powers, he does not use the term "séparation des pouvoirs" in his work The Spirit of the Laws, but rather mentions the distribution of powers. This does not exclude the fact that his work presented a fundamental impetus for the constitution of this idea. The idea of a strict separation of powers undoubtedly had its argumentative power: It is noteworthy, for example, that one of the objections to the U.S. Constitution was that it blended different kinds of power and that it was not truly consistent in their separation. ${ }^{9}$ James Madison responded to this criticism by accepting that the accumulation of legislative, executive, and judiciary powers in same hands means tyranny, however, in his view, the doctrine of the separation of powers should not mean that the different kinds of power should be completely independent of each other. According to Madison, this was also how Montesquieu understood it, as supported by the constitutional order in Britain where these kinds of powers had never been totally separated. ${ }^{10}$ In other words, in the construction of the U.S. Constitution, the strict separation of powers had to make way for other tendencies, in particular for those resulting from the need of in-

8 In connection with this consideration, cf. Jan Kysela's distinction between the separation of powers in the functional sense and institutional sense. J. Kysela, Ústava mezi právem a politikou: úvod do uistavni teorie, Praha 2014, p. 287.

9 J. A. Fairlie, The Separation of Powers, "Michigan Law Review"1923, no. 4, p. 397.

10 For details, vid. ibid, pp. 398-399. Also cf. various considerations on the separation of powers directly in the Federalist Papers: A. Hamilton, J. Madison, J. Jay, The Federalist, Indianapolis 2005 , p. 262 et seq. 
tegration. The approach of the Founding Fathers thus did not stem from some leading theory on the separation of powers but was rather of a pragmatic character. ${ }^{11}$

The fact is that the idea of the strict separation of powers traditionally faced a large number of objections, especially during the 19th century: the Swiss lawyer and politician Johann Kaspar Bluntschli argued that the complete separation of powers would be the end of the unity of the state. ${ }^{12}$ Similarly, the French administration law theorist Leon Duguit stated that the idea of the separation of powers was incompatible with the idea of the indivisibility of sovereignty and that the very idea of one sovereign power within three is a metaphysical concept analogous to the Holy Trinity, which is inadmissible in a truly positive construction of public law. ${ }^{13}$ The American academic Westel Woodbury Willoughby then warned that the complete application of this principle is prevented by the practical requirement for effective governance. ${ }^{14}$ Finally, these objections were well summarized and supplemented by French lawyer Raymond Carré de Malberg in his Contribution à la théorie générale de l'Etat. This author considered the concept of pluralism to be incompatible with the essential unity of the state. The absolute independence of state bodies would, in his view, be impractical, 15 just as their equality would be legally impossible. There would always be one body that would have superiority over others. ${ }^{16}$

Generally, two distinct questions were combined in the criticism of the separation of powers - the separation of functions and the independence of state bodies. While absolute independence between individual organizational units would indeed undermine the unity of the state, the argument of its impracticability and unfeasibility is directed primarily against the separation of functions. Of course, it must be admitted that even the disintegration of the unity of the state would influence the efficiency of the realization of its functions - it ultimately leads to impracticality.

The separation of functions can be considered a kind of division of labour. Its value, among other things, lies in increasing the efficiency of the whole system, ${ }^{17}$ which is aided by the specialization of individual state bodies for the realization of certain functions. Illustrative in this context is a reference to the fact that if statutes were enforced by the person who created them, that person would not be motivated to make them free of flaws since it would be possible to later "repair" statutes relatively easily in the process of

11 S. W. Cooper, Considering "Power" in Separation of Powers, in: "Stanford Law Review", 1994, no. 2, p. 366.

12 J. Fairlie, op. cit., pp. 412-413.

13 Ibid., p. 420.

14 Ibid., p. 405.

15 The argument of the impracticability of strict separation of powers can also be found in the present literature. Vid., e.g., E. Carolan, op. cit., p. 19.

16 J. Fairlie, op. cit., p. 422.

17 The importance of the relationship between the separation of powers and effective governance is implicitly described in E. Carolan, op. cit., p. 22. 
their application. It is important, however, that their truly strict separation is not (and has never been for most of the past) really pursued..$^{18}$ For example, according to Victoria Nourse, the fact that individual state bodies exercise their functions as well as the functions of other bodies is an open secret. ${ }^{19}$ Similar approaches can be reliably shown throughout history. ${ }^{20}$ On the contrary, the question of how independent state bodies should be of each other is one of the constantly recurring problems. Yet, the emphasis on their autonomy still remains alive. ${ }^{21}$

\section{The System of Checks and Balances and its Relationship to Institutional Independence}

Within the intentions of the system of checks and balances, we no longer strive for the strict separation of state functions, nor for the greatest possible independence of state bodies, but rather for a balanced relationship between them. James Madison may be viewed as one of the fathers of this concept, as he outlined it in the famous Federalist Papers. ${ }^{22}$ Maxim Tomoszek explicitly states in one of his texts:

- In overall, we can say that although the separation of powers is primarily perceived as a principle guaranteeing democracy, its main importance lies in ensuring the existence of the rule of law by dividing the tasks of creation and application of law among individual powers, thus ensuring a certain balance. ${ }^{23}$

The idea of balance is characteristic of the system of checks and balances.

The problem of the interrelation of this principle with the other components of the separation of powers has already been outlined in part. These are a few separate prin-

18 In the context of Great Britain, this had already been claimed by John A. Fairlie. Vid.J. Fairlie, op. cit., p. 397. Also cf. L. Claus, Montesquieu's Mistakes and the True Meaning of Separation, in: "Oxford Journal of Legal Studies", 2005, no. 3, pp. 427-428. P. B. Kurland, The Rise and Fall of the "Doctrine" of Separation of Powers, in: "Michigan Law Review", 1986, no. 3, p. 603.

19 V. Nourse, The Vertical Separation of Powers, in Duke Law Journal 1999, no. 3, p. 758. To this, cf. some of the considerations in L. Claus, op. cit., p. 445.

20 Cf., e.g., J. A. Fairlie, op. cit., pp. 402-403.

21 Cf., e.g., the statement of President of the Constitutional Court of the Czech Republic Pavel Rychetský that the separation of powers encourages the tendency to maximize autonomy. P. Rychetský, Několik poznámek ke stavu české justice s prìblédnutím k dẽlbě moci, in: Délba soudni moci v České republice, ed. V. Hloušek, V. Šimíček, Brno 2004, p. 15.

22 Vid. A. Hamilton, J. Madison, J. Jay, op. cit., p. 280 et seq. Madison also rejects the idea of the strict separation of powers and supports his argumentation by an analysis of Montesquieu's views, from which Madison concludes that Montesquie himself did not strive for it. To this, cf. ibid., p. 262 et seq.

23 M. Tomoszek, Délba moci jako podstatná náležitost demokratického právního státu, in ed. J. Jirásek, Délba moci. Sbornik príspěvkiu sekce ústavního práva, prednesených na mezinárodni védecké konferenci Olomoucké prárnické dny 2013, Olomouc 2014, p. 249. 
ciples that are not necessarily mutually supportive. According to Mary Elizabeth Magill, attempting to articulate how separation can lead to balance among the departments is a fruitless enterprise. ${ }^{24}$ This is why the system of checks and balances is sometimes considered as an element correcting the tendency to the excessive autonomy of some state bodies.

The problem is that while the requirement for separation remains relatively easy to articulate in itself, the idea of balance is much more difficult to grasp. If we put different goods on the scales, we can easily tell when the balance has been reached between the two sides. But what to do when we need to find the balance between (usually more than two) state bodies? What does balance mean in this respect? I am afraid it means nothing more than a relatively well-functioning state with which we are subjectively satisfied. It seems that we have no real idea at hand here.

Another of our questions has a noetic character: How we do tell that a system is in balance? Jiř́ Baroš argues that we lack an analytical tool that would allow us to find out. ${ }^{25}$ Even if we had it, it cannot be ruled out that the system could achieve balance in several different states. Which one should we choose then? In certain situations, perhaps it would be helpful to find some state that we could call "optimal." However, this would only move the problem to how to tell which state can be considered the best. In principle, it is much easier for people to agree on what bothers them than on some ideal arrangement. Uncertainty still persists, not only in the question of what should be the result of the system of checks and balances - according to Magill, it is also not even clear through which mechanism we should achieve such a balance. ${ }^{26}$

In this situation, the question arises whether we do not create the system of checks and balance by the method of trial and error in response to random historical events. The very idea of balance itself may be based only on a social convention, a certain calculation with the default situation. In other words, if the current variant of the institutional arrangement suits us and does not cause any major problems, we only respond to its fluctuations (e.g., increase in the independence of the President's position as a result of a direct election), which we try to compensate for by randomly chosen adjustments. However, this does not even indicate the real functionality of such an arrangement or its optimal character, all the more so that this functionality might be influenced by a number of other factors and not only by the arrangement of the system of checks and balances itself.

The very nature of the balance that we strive for is a different set of problems. Are we trying to establish only the institutional balance, i.e., to balance the position of individual state bodies, or the power balance directly, i.e., to balance the position of individual power centres? It would be ideal if both were overlapping. However, we could give

24 M. E. Magill, The Real Separation in Separation of Powers Law, in "Virginia Law Review”, 2000, no. 6, p. 1130.

25 J. Baroš, Délba moci jako nástroj konstitucionalismu, „Jurisprudence” 2013, no. 7, p. 15.

26 M. E. Magill, op. cit., p. 1166. 
many examples when this is not the case. Some could argue that the original separation of powers between individual legislative and executive institutions has been replaced by the division between the parliamentary majority and the opposition. ${ }^{27}$ This argument is correct. But has this been sufficiently theoretically considered? And have all the consequences of this shift really been taken into account? The notion that the judicial power is to be protected from the executive power may also be viewed as misleading. This could perhaps have been relevant in the times of the Federalists, when the two powers were made up of only a handful of people. It no longer makes sense in the context of the current bureaucratic administrative state, where those organizational units have grown considerably. That is why we would find it difficult today to assign them some unified goals and intentions. At present, we do not have to protect the judiciary from some pressure from this executive power, but from the pressure of some political elites who have become accustomed to using some state bodies as their instruments of influence. This has resulted in a shift in the power centre.

To summarise, considering the separation of functions - or balancing the position of individual state bodies through the system of checks and balances - does not mean that we are actually managing to control power and balance power centres. The balance does not have to overlap with the division into state bodies. The balance between power centres is especially needed to prevent dominance and the ensuing tyranny by one of them. This corresponds to the purpose that is usually attributed to the separation of powers. The components of the separation of powers (system of checks and balances) are primarily aimed at ensuring institutional balance, through which they contribute to the power balance. It is logical if relations between institutions also reflect potential threats from the actually existing power centres. Such relations are certainly not determined only by them. The requirements for their efficiency and the need for their practical functionality, etc., can also be important. It is understandable that the system of checks and balances was created in response to real power risks. If they change over time, this should also be taken into account.

\section{The Purpose of the Separation of Powers}

Now, it is time to think about the purpose of the separation of powers, or rather about the above-defined principles. If we were to investigate the purpose of the separation of powers from a historical perspective, both of its originators - John Locke and Charles Louis Montesquieu - followed the idea that too much concentration of power eventu-

27 Vid. V. Klokočka, Poslanecký mandát v systému reprezentativní demokracie, Politologický časopis 1996, no. 1, p. 24. 
ally leads to its abuse. ${ }^{28}$ As a result, the purpose of their separation is treated in their theoretical works primarily as an attempt to prevent such abuse. It is possible to agree with Jeremy Waldron's claim that there is a consensus on the importance of the separation of powers in order to prevent tyranny. ${ }^{29}$ However, as the same author correctly pointed out, this importance is only claimed, without anyone actually explaining it (including Montesquieu himself). ${ }^{30}$

Moreover, such a purpose of the separation of powers significantly narrows its possible application. For example, the attempt of President of the Czech Republic Václav Klaus to dismiss Iva Brožová from the post of President of the Supreme Court would certainly not make him a tyrant, and the Czech Republic a tyrannical state, if his attempt was successful. In such a situation, it would either be inappropriate to argue using the separation of powers or we would have to understand its purpose in a different way - as the optimization of governance. We would no longer only want to prevent the worst, but to achieve the best. The minimalist concept of the separation of powers could be replaced by a much broader and more flexible concept in which the question of whether the President of the Czech Republic can remove the President of the Supreme Court could be meaningfully asked. Whether it could be answered at all - whether we really can tell which result would lead to the optimization - is another matter.

Of course, it can be argued against this that tyranny may be established by the method of gradual erosion and decay rather than through a single radical gesture. It is difficult to determine where the precise boundaries between good governance and tyranny lead. It is more about whether we are coming closer to tyranny or moving away from it, rather than whether it is tyranny or not. Here, too, we have to work with some conception of ideal standards - we must have an idea of perfect good governance and or perfect tyranny, while considering whether a particular step is closer to the former or latter. In addition, we may still encounter the problem that some steps may not be evaluable in this context.

In the example above, it is easy to see how the purpose of the separation of powers can form its application in specific cases. Preventing tyranny was undoubtedly one of its key objectives, however, the question is whether it is enough for us today and whether the separation of powers has not become a frozen concept. Fortunately, there is no doubt that there may be many such purposes which, in most situations, can complement and support each other. The problem arises only when different requirements are imposed on the separation of powers that are not fully compatible. ${ }^{31}$ How such a conflict

28 Vid., e.g., Locke's critique of absolutism in J. Locke, Second Treatise of Governmen, Indianapolis 1980 , p. 48 et seq. Also Montesquieu's famous passage on freedom and the separation of powers in Ch. Montesquieu, The Spirit of Laws, Kitchener 2001, p. 173.

29 J. Waldron, Separation of Powers or Division of Power, in "Public Law \& Legal Theory Research Paper Series" 2012, no. 12-20, p. 1.

30 Ibid, p. 1 and 120. Also cf. J. Waldron, 2016, op. cit., p. 60.

31 E. Carolan, op. cit., p. 28. 
between different purposes can be solved remains an open topic, not only in this field but also in law in general. Given the current state of knowledge, the application of the principle of proportionality and some forms of methodology linked to it may turn out to be the best option.

Which purposes can we trace in the background of the separation of powers? Besides the above-mentioned protection against tyranny, Eoin Carolan mentions the following as normative reasons that justify the separation of powers:

- Secure a balance between institutions such that they are capable of supervising each other's actions through a system of checks and balances;

- Ensure law is made in the public interest by establishing a balance of power between institutions, or representative groups;

- Enhance efficiency by giving responsibility for individual tasks to the most appropriate institutional actors;

- Prevent partiality and self-interest by separating the personnel involved in decision-making;

- Ensure objectivity and generality in the creation of laws by separating the tasks of law creation and law enforcement;

- Allow elected and representative officials to supervise the actions of executive officials and call them to account if necessary. ${ }^{32}$

Nevertheless, Carolan criticizes the theory of the separation of powers for not being clear in what it protects exactly - whether freedom, efficiency, individuals, or public interest. $^{33}$

At first glance, it is obvious that some of the above-mentioned purposes lead to the separation of functions, while others aim to ensure the independence of individual state bodies, or a balanced relationship between them. A common goal of all the principles on which a government system can be organized is to ensure good governance. This is true both for the separation of functions and for the requirements regarding institutional independence and the system of checks and balances. Good government can also be characterized as effective, ensuring freedom ${ }^{34}$ and a good life for individuals, and avoiding arbitrariness. We can also think of it as limited government.

Within this framework, one of the distinctions made by Jeremy Waldron is also interesting. In Anglo-English literature, we can often encounter not only the term limited government, but also restrained or controlled government. Waldon warns us that these terms are not synonymous (though they are mistakenly used as such) - on the contrary, they mean different things. ${ }^{35}$ For example, control is not only negative: if

32 Ibid., pp. 27-28.

33 Cf. ibid., p. 254.

34 To this, cf. also F. Weyr, Československé právo uistavni, Praha 1937, p. 21.

35 J. Waldron, 2016, op. cit., p. 30. 
someone has a car under control then they know both where they can go and where they cannot. ${ }^{36}$ However, restriction is never a positive notion - it only should prevent the government from doing certain things. ${ }^{37}$ Therefore it might be sometimes difficult to distinguish it from limitation. Waldron sees the key difference between them lying in the fact that while the meaning of the former is to avoid a misuse, the latter is a broader concept related to the fact that some aspirations of government are illegitimate in themselves (such as aspirations to interfere with religious freedom). ${ }^{38}$

If we go back to the above-described purposes, we can say that the components of the separation of powers lead to more of them, but they differ in that to some of them they lead primarily, while to others only secondarily - through the fulfilment of other goals. For example, the separation of functions primarily aims at achieving efficiency (and thus contributing to the well-being of individuals). Specialization is related to better knowledge of problems and greater performance.

Personally, I do not consider it appropriate to combine the purpose of the separation of powers with the prevention of tyranny. Because what else is tyranny other than allowing arbitrariness? ${ }^{39}$ Arbitrariness can take place also within a single state body in the performance of one of its functions unless control is ensured. It may seem that the advantage that lies in this principle is that such tyranny will never be as complete as if it is committed by someone who holds all the functions in their hands. However, if, for example, the courts decided arbitrarily for a long time and nobody prevented them from doing so, would not the work of all other state bodies go down the drain with it? The realization of law is a complex process - if one of its components is eliminated, it brings into the lives of people consequences so severe that it makes no sense to compare it with a situation where more of its component are disturbed. It does not matter if a tripod loses one leg or two - it will not stand in either case.

On the contrary, the introduction of the system of checks and balances should prevent the arbitrary procedure of individual state bodies by ensuring their control. It is to be expected that a state body that does not proceed arbitrarily and works under adequate supervision will also act more efficiently.

It is the balanced position of individual state bodies that is supposed to be a barrage against tyranny. In connection therewith, the following comment by František Zoulík is worth mentioning:

36 Cf. ibid., pp. 30-31.

37 Ibid, p. 31.

38 Cf. ibid., pp. 31-32.

39 To define the notion of arbitrariness, cf. J. Volková, Právni akty svévolnébo zákonodárce, in Časopis pro právní vědu a praxi 2015, no. 2, p. 119 et seq. 
In the conditions of a modern state, the meaning of the separation of powers as a constitutional principle no longer lies in the limitation of absolute power but in the protection against the seizure of control over state institutions and against legislative enforcement of political programmes regardless of legal principles. ${ }^{40}$

This is a good indication of the importance of historical contexts for understanding the separation of powers. ${ }^{41}$ It is natural that at a time when the exercise of all functions (at least officially) was unified in the hands of a single person, the major problem was seen in that unification. In fact, however, the problem lay in the fact in that many people tended to abuse their position if they were not under sufficient control.

\section{Conclusion}

The principle of the separation of powers consists of several very different components, between which there is a strong tension. This tension cannot be eliminated by reference to the purpose of the separation of power. It is therefore particularly difficult to determine if we should emphasize the independence of state bodies or the checks and balances between them. The second part of my paper will be dedicated to the different ways of dealing with this issue.

\section{Literature}

Baroš J., Délba moci jako nástroj konstitucionalismu, Jurisprudence no. 7., 2013.

Carolan E., The New Separation of Powers: A Theory for the Modern State, New York 2009. Claus L., Montesquieu's Mistakes and the True Meaning of Separation, Oxford Journal of Legal Studies 2005, no. 3.

Cooper S. W., Considering "Power" in Separation of Powers, Stanford Law Review 1994, no. 2 .

Fairlie J. A., The Separation of Powers, Michigan Law Review 1923, no. 4.

Hamilton A., Madison, J., Jay J., The Federalist. Indianapolis 2005.

Klokočka V., Poslanecký mandát v systému reprezentativni demokracie, Politologický časopis 1996, no. 1.

Kurland P. B., The Rise and Fall of the "Doctrine" of Separation of Powers, Michigan Law Review 1986, no. 3.

40 F. Zoulík, Soudy a soudnictvi, Praha 1995, p. 73.

41 The idea that times and their contexts change, which we have to take into our consideration of the separation of powers, is also shared by M. J. C. Vile, op. cit., p. 3. 
216 | Adam Mickiewicz University Law Review

Kysela J., Ústava mezi právem a politikou: úvod do ústavni teorie, Praha 2014.

Locke J., Second Treatise of Government, Indianapolis 1980.

Magill M. E., The Real Separation in Separation of Powers Law, Virginia Law Review 2000, no. 6 .

Montesquieu Ch., The Spirit of Laws, Kitchener 2001.

Nourse V., The Vertical Separation of Powers, Duke Law Journal 1999, no. 3.

Rawls J., The Idea of an Overlapping Consensus, Oxford Journal of Legal Studies 1987, no. 1.

Rychetský P., Několik poznámek ke stavu české justice s prìlédnutím k dèlbè moci, Dèlba soudni moci v České republice, ed. V. Hloušek, V. Šimíček, Brno 2004.

Tomoszek M., Délba moci jako podstatná náležitost demokratického právního státu, in Délba moci. Sbornik príspèvkư sekce ústavního práva, přednesených na mezinárodni védecké konferenci Olomoucké právnické dny 2013, ed. Jirásek, J., Olomouc 2014.

Vile M. J. C., Constitutionalism and the Separation of Powers, Indianopolis 1998.

Volková J., Právní akty svévolnébo zákonodárce, Časopis pro právní vědu a praxi 2015, no. 2.

Waldron J., Political Political Theory. Essays on Institutions, Cambridge, London 2016.

Idem, Separation of Powers or Division of Power, Public Law \& Legal Theory Research Paper Series 2012, no. 12-20.

Weyr F., Československé právo ústavní, Praha 1937.

Zoulík F., Soudy a soudnictví, Praha 1995.

SUMMARY

\section{Is Separation of Powers Useless Concept? Components and Purpose of Separation of Powers}

In this paper, the author raised the question of whether the separation of powers is a useless concept. It points out to insufficient reflection of its theoretical and philosophical origins. The paper also distinguishes its components, which it then analyses in more detail. Great attention is dedicated to the tension between the system of checks and balances and the institutional independence. It also examines the purpose of the separation of powers, warning that we can no longer seek it exclusively in the prevention of tyranny but rather in the optimization of government. At the end of the paper is emphasized the need to examine the question of how to solve tension between these components.

Keywords: Separation of powers, state functions, checks and balances, independence, political theory

Martin Hapla, Faculty of Law, Masaryk University, Veveři 70, Brno 611 80, Czech Republic, e-mail: martinhapla@gmail.com. 